YAŞLILIK ÇALIŞMALARi Dergisí | JOURNAL OF Aging STUDies

Teorik Müdahaleler

Theoretical Interventions

\title{
Kentte Yaşlanma ve Yaş Dostu Kentler: Eleştirel Bir Değerlendirme
}

\author{
Işıl Avşar Arık \\ Doktora Öğrencisi, Necmettin Erbakan Üniversitesi, Sosyoloji Bölümü \\ E-Posta: avsarisil@gmail.com
}

Geliş Tarihi: 20 Haziran 2021; Kabul Tarihi: 13 Ağustos 2021

Doi: 10.24876/senex.2021.38

Künye: Avşar Arık, I. (2021). Kentte Yaşlanma ve Yaş Dostu Kentler: Eleştirel Bir Değerlendirme. Senex: Yaşlılık Çalışmaları

Dergisi, 5(1), 47-63.

(D) 0000-0002-3974-693X

\section{Özet}

Yirmi birinci yüzyılın toplumsal değişmeleri arasında demografik dönüşüm ve kentleşme önemli bir yer tutar. Demografik dönüşümle birlikte yaşlı nüfus oranı tüm dünyada artarken, genel nüfusun kentlerde yoğunlaşmasıyla birlikte kentlerde yaşayan yaşlı nüfusta da artış görülmektedir. Öte yandan 1980 sonrası ortaya çıkan neoliberal politikalar kentlerin fiziki yapılarıyla birlikte, toplumsal ve kültürel boyutlarında da önemli değişikliklere sebep olmaktadır. Bu değişim, eleştirel kentleşme teorileri tarafından tartışıırken, konuya yaşılır açısından bakan çalışmalar oldukça sınırlı kalmıştır. Kentte yaşlanmaya dair neoliberal politikalar ve yapısal faktörler yeterince değerlendirilmemiş; yaşam kalitesi, yerinde yaşlanma, aktif ve başarılı yaşlanma gibi kavramlar etrafında sıklıkla çalışılmışve son yıllarda bu kavramların daha geniş bir uygulaması haline gelen Dünya Sağlık Örgütü'nün sunduğu Yaş Dostu Kentler ve Topluluklar (YDKT) düşüncesi oldukça kabul görmüştür. Fakat YDKT'nin teorideki doygunluğuna, neoliberal kentleşme pratikleri sebebiyle uygulamada tam anlamıyla ulaşılamamış, bu nedenle birçok eleştirinin hedefi haline gelmiştir. Eldeki çalışma bu doğrultuda kentlerin neoliberal ekonomi politiğini, bunun yaşlıların kenti deneyimleme noktasındaki etkilerini ve YDKT'nin neden bu eleştirilerin hedefinde olduğunu detaylı olarak tartışmayı amaçlamaktadır. Son olarak ise kentte yaşlanma konusunda hak temelli perspektif ışığında önerilerde bulunmaktadır.

\author{
Anahtar Kelimeler: \\ Yaşlılık • Kentleşme • Kentte Yaşlanma • Yaş Dostu Kentler • Kent Hakkı • Neoliberalizm \\ Urban Aging and the Age Friendly Cities: A Critical Approach
}

\begin{abstract}
Demographic transformation and urbanization are two important phenomena in the twenty-first century. With the demographic transformation as the population aging increases all over the world, due to the concentration of the general population in cities the aging population living in cities increase. On the other hand, the neoliberal economy politics that revealed after 1980, have been caused substantial changes in the aspect of physical at first and then social and cultural. This transformation in cities has been discussed by critical urban theories, however, the debates on this subject which sees from the aspect of the older adult stayed very limited. Neoliberal policies and structural factors on urban aging have not been adequately evaluated. The subject of urban aging has studied frequently with the concepts such as active aging, successful aging, and aging-in-place in recent years, and the idea of Age Friendly Cities and Communities (AFCC), put forward by the World Health Organization, which has become a wider application of these concepts in recent years, has been widely accepted. However, the saturation of AFCC in theory has been limited in practice due to neoliberal urbanization practices; therefore, it has become the target of many criticisms. Within the context of these critics, this study aims to argue neoliberal economy politics of cities besides the impact of said politics on the experience of the older adult and why the AFCC has been targeted by these criticisms. Finally, in doing so, makes some recommendations in the light of right-based perspectives concerning urban aging.
\end{abstract}

\section{Keywords:}

Aging • Urbanism • Aging in Urban • Age Friendly Cities • Right to the City $•$ Neoliberalism 


\section{Giriş}

Doğurganlığınazalmasıvedoğumdabeklenen yaşam süresinin artmasıyla birlikte (United Nations, 2017) teknolojideki gelişmeler geçtiğimiz yüzyıllara göre yaşlı nüfus oranını daha yüksek seviyelere ulaştırmıştır. Demografik dönüşüm olarak isimlendirilen (Unied Nations, 2017) bu süreç ve kentleşme hızındaki artış, yirmi birinci yüzyılın öne çıkan toplumsal olgularının önemli iki başığı olarak değerlendirilmektedir (Arun, 2020; Moulaert ve Garon, 2016; Phillipson, 2010; Wanka, Moulaert ve Drilling, 2018; WHO, 2007; Woolrych ve Sixsmith, 2020). Toplumun tüm katmanlarında doğrudan veya dolaylı yollarla değişim yaratma potansiyeline sahip olan demografik dönüşüm "yaşlı" olarak tanımlanan 60 yaş ve üzeri nüfus oranının toplam nüfustaki artışını ifade etmektedir. (Moore ve Pcey, 2004: 6). 2017 yılında dünya nüfusunun yaklaşık \%13'ü 60 yaş ve üzeri iken, bu oran her yıl ortalama \%3 oranında artmaktadır. Günümüzde Avrupa \%25 ile en yüksek yaşlı nüfusa sahipken, dünyanın diğer tüm bölgelerinde de 60 yaş ve üzeri nüfus hızla artmaktadır. Bunun sonucunda 2050 yılına gelindiğinde, dünya nüfusunun çeyreğinden fazlası 60 yaş ve üzerinden oluşacaktır. 2050 yılında yaşlı nüfusun 2,1 milyar olacağı tahmin edilmektedir (United Nations, 2017). Günümüzde, tüm dünyada nüfusun yaklaşık \%50'sinin kentlerde yaşamasıyla birlikte, yirmi birinci yüzyılın ortalarında, gelişmekte olan ülkelerin çoğunun önemli oranda kentleşmiş olacağı öngörülmektedir (Phillipson, 2010: 597). Dünya Sağlık Örgütü (WHO), kentlerin büyümesiyle beraber 60 yaş ve üzeri nüfusun aynı anda büyüdüğünü belirtmektedir (2007: 1-2). 2030 yılına kadar gelişmiş ülkelerde kentlerdeki yaşı nüfusun \%25'i aşacağı öngörülmektedir (Moulaert ve Garon, 2016). Bu dönüşüm birçok ülkenin kapsayıcı ve sürdürülebilir politikalar üretmesini gerektirmektedir (Arun, 2020: 1). Tüm bu veriler yaşlılıkla ilgili çalışmalarda kent ve kentleşme boyutunun yanı sıra kentlerdeki toplumsal ve kamusal mekânlarla yaşlılar arasındaki ilişkinin önemini ortaya koymaktadır. Kentlerde yaşayan yaşlı nüfusun artışı kentin toplumsal mekânlarında birtakım düzenlemeleri gerekli kılmaktadır.

Kentler ve kent mekânları ilk bakışta fiziki bir çevreye sahipmiş gibi görünse de bu alanlar fiziki yapılarının yanında sosyal, kültürel, ekonomik, vb. ilişkileri şekillendiren toplumsal bir temele de sahiptir. Bu yönüyle, toplumsal mekânlar olarak da isimlendirilebilecek kentsel mekânlar gündelik hayatı ve toplumsal pratikleri şekillendirmede son derece etkilidir. Stavrides'in (2016: 11) de belirtmiş olduğu gibi, insanlar mekânı tecrübe etmekle kalmaz, aynı zamanda mekân aracılığıyla düşünür ve hayal kurar. Harvey ise kentin mekânsal biçiminin insan davranışı üzerinde temel bir belirleyici olduğunu düşünmektedir (2008: 47).

Günümüzde kentlerdeki değişim ele alındığında, metropoliten alanlardan çok merkezli kent alanlarına doğru bir şekillenmenin olduğu, kentlerin kendi arasında ekonomik rekabetin arttığı, sermayenin kendini kent mekânları üzerinden yeniden dönüşüme soktuğu görülmektedir (Şentürk, 2019: 64-65). Sosyo-mekânsal değişimi ifade eden "kentsel dönüşüm" ise 1980'lerin ikinci yarısından itibaren başlamış ve daha sonra birçok kente sıçramıştır. Demokratik katılımın olmadığı ve hızlı bir şekilde kentlerin dönüşümünün gerçekleştiği bu süreçte yaşlılar kentsel dönüşüm çalışmalarında pek yer verilmeyen, genellikle göz ardı edilen kesim olmuştur (Kurtuluş, 2019: 80). Bu iki önemli değişmenin yansıra, soylulaştırma çalışmaları da son zamanlarda dikkat çeken diğer bir konudur. Kent yaşamında meydana gelen bu değişmelerle uzun süredir kent merkezlerinde yaşayan yaşlılar hem ekonomik hem de toplumsal açıdan yeni mekânlara uyum sağlamakta zorlanmakta ve bundan dolayı da kent mekânlardan giderek uzaklaşmaktadır. 
Yaşlıların kenti kullanım pratikleri değişmekte, bunun sonucunda kent içinde ve dışında farklı mekânlara itilmektedirler (Şentürk, 2019: 6465).

Kente dair tüm bu yapılanmalar 1980 sonrası ortaya çıkan neoliberal politikalar bağlamında değerlendirilebilir. Bir toplumdaki bireylerin ekonomik düzey, eğitim, inanç, etnik köken vb. gibi özelliklerine bağlı olarak farklı mekânlarda kümelenmelerini ifade eden sosyo-mekânsal ayrışma ise neoliberalizmin kentsel alandaki en önemli çıktısı olarak ele alınabilir. Şentürk'ün de (2019: 64) belirttiği gibi, bu çerçeve kentlerde son dönemdeki ekonomik dönüşümün yanında toplumsal dönüşümün de yaşandığının ve bu durumun yaşılırı etkilediğinin en bariz örnekleri olarak düşünülebilir.

\section{Kentleşme ve Sosyo-Mekânsal Ayrışma: Sürece Yaşlılar Açısından Bakmak}

Kent sosyolojisi, şehirleri, modernitenin mekânları bağlamında ele alırken, kapitalist ekonomik sistemin kentleri nasıl inşa ettiğini göz ardı etmiştir (Savage ve Warde, 1993: 34). Kent, 1970 'lerden sonra Marksist literatür içerisinde kendine önemli bir yer bulmuş ve kapitalizm Castells, Lefebvre ve Harvey gibi isimlerce kent, mekân ve sermaye merkezli olarak ele alınmıştır. Bu tartışmalarda kent, kapitalist sistem içerisinde ayrı bir değişken olarak, son derece önemli bir rol oynamaktadır (Merrifield, 2017: 25). Günümüzde kentler bir yandan hızlı bir büyüme gerçekleştirirken, diğer yandan bazı kişiler veya toplumsal gruplar için yeni mücadele alanlarına dönüşebilmektedir (Phillipson, 2010: 598). Bu sebeple kentin politik bir özne olduğu söylenebilir (Merrifield, 2017: 25).

Kente dair eleştirel bakış açısı sunan bu çalışmalar kenti inşa edilmiş, yaratılmış bir çevre olarak ele almanın yanı sıra, onu bir ideoloji ve kapitalist birikim süreçleri çerçevesinde de değerlendirmişlerdir. Bu yönüyle mekân kavramı da üretim, yeniden üretim, kolektif tüketim, yeni toplumsal hareketler ve sermaye birikimi bağlamında tartışılmıştır.

Mekânsal tartışmalar insanların deneyimlediği gündelik hayatın nasıl örgütlendiğini anlamak bakımından önemlidir; siyasi ve maddi koşullar arasındaki ilişkiyi açıklığa kavuşturabilirler (Castells [1978], 2014). Harvey kapitalist siyasetin sürekli artı değer üreterek genişlemesini ve kentlerin bu artı değeri hem üretmede hem de bunu soğurmasında merkezi bir rol oynadığını vurgular. Bu nedenle ki kapitalizmin gelişmesi ile kentleşme arasında anlamlı bir ilişki vardır (Harvey, 2015: 45-47). Harvey bu süreci "yeni kentleşme" pratikleri olarak isimlendirirken, bu sürecin, tüketimin aşırıya kaçmasını, her yerde tüketim mekânlarının inşa edilmesini ve kentsel dönüşümleri beraberinde getirdiğine dikkat çeker. Kendi sözleriyle bu, "mülkiyet hırsından beslenen aşırı bireyciliğe dayalı neoliberal ahlakın, benliğin toplumsallaşması için model teşkil ettiği bir dünyadır". Bu dünyanın sonuçları ise kentlerde yalıtılmışlık hissi, ötekileştirilme ve endişe halidir (Harvey, 2015: 56).

Neoliberal ahlak, günümüz kentlerinde maddi tüketim ürünlerden maddi olmayan davranış ve düşünme kalıplarına kadar yaşamın her alanını sarmış durumdadır. Hareket stratejisi her zaman daha fazla kazanmak ve maksimum kar elde etmek olan neoliberal politikalar devlet ve sermaye arasındaki ilişkiye odaklanır ve sermayenin baskın olduğu bir toplumsal ortam yaratır. Bu anlamda neoliberalizm, devlet müdahalesine karşı sermaye ve piyasanın çıkarlarının ideolojisi olarak tanımlanmaktadır (Filho, 2014: 25-26). Böylece kent yönetiminin neredeyse tamamının piyasa merkezli olarak hareket etmesi, kent yönetimini ekonomik ve sınıfsal bir temele indirger. Bu yapı içerisinde orta ve alt sınıflar olumsuz olarak etkilenir. 
Kentin nasıl bir anlama sahip olduğu ve içerisinde yaşayan farklı kesimler tarafından nasıl deneyimlendiği ise son zamanlarda bu çerçevede sosyal, politik ve ekonomik olarak inşa edilmiş bir mekân anlayışı çerçevesinde tartışılmaya başlanmıştır.

Kentin sosyal olarak inşa edildiğini belirten görüşler Lefebvre'in mekân üretimi üzerine olan düşüncelerinden etkilenmişlerdir. Buna göre mekân kapitalist toplumlarda bir meta olarak ortaya çıkmaktadır. Bu nedenle mekânın fiziksel ve coğrafi anlamıyla tartışılması yeterli değildir, o kapitalist güçlerin üretiminin bir sonucu olarak politik bir şekilde inşa edilmektedir (Savage ve Warde, 1993). Lefebvre'in kente bakış açısı ile gündelik hayatın nasıl anlamlandırıldığına dair fikirleri "Kent Hakkı" olarak ifade ettiği kavramsallaştırma üzerinden de okunabilir (Torlak, 2016: 18).

Kentteki toplumsal mekânlara erişim hakkını içeren kent hakkı fikri, kent ve yaşam alanlarının kentte yaşayanlar tarafından kullanılmasına olanak tanıyan bir bakış sunar (Mitchell, 2014: 39). Böylece kent hakkı üstün bir hak olarak yapıt (ouevre), katılım ve sahiplenme (appropriation) hakkı şeklinde ortaya çıkar (Lefebvre, 1996: 174; 2017: 151). Lefebvre'nin ouevre (yapıt) ile kastettiği şey, üründen çok farklıdır. Ouevre hakkı, kentte yaşayan farklı kesimlerin, kente ve kendilerine yabancılaşmadan, kenti kendi istek ve intiyaçları doğrultusunda, hep beraber bir sanat eseri gibi işlemeleridir. Lefebvre sahiplenme hakkının ise özel mülkiyetle karıştırılmaması gerektiğini, (Lefebvre, 2017: 151), bu nedenle kent hakkının, kent içerisinde yaşayanlara zamanı ve mekânı tam anlamıyla kullanmalarına olanak tanıdığını (Lefebvre, 1996: 179) belirtir. Bununla birlikte, sahiplenme hakkının kullanım değeri ile ilişkilendirilebileceğini söyler (Lefebvre, 1996: 20). Kent hakkı, kent yaşamından bütün olanakları ile tam anlamıla faydalanma hakkıdır (Lefebvre, 2017: 158). Modern şehirlerde kamusal mekânlar giderek, içerisinde yaşayanlar tarafından değil, onlar için üretilmeye başlanmıştır. Fakat insanların daha fazlasına hakkı vardır (Mitchell, 2014: 38). Insanların güvenlik ve serbestlik ihtiyacı, çalışma ve oyunun örgütlemesi ihtiyacı, görme, algılama, işitme gibi ihtiyaçlarını karşılamakta şehirler yetersiz kalmaktadır (Lefebvre, 2017: 119). Lefebvre'e göre kent hakkı; özgürlük hakkı, toplumsallık içinde bireyselleşme hakkı, yaşam alanı ve mesken hakkını ihtiva eder (Lefebvre, 2017: 151). Şehirlerde kullanım değerinin değişim değerini önceleyebilmesi, etkileşim ve karşılaşma alanlarına erişim hakkını barındıran kent hakkı ile sağlanabilir (Mitchell, 2014: 39). O, hem bir haykırış (çığlık), hem de bir taleptir (Lefebvre, 2017: 132). Haykırıştır, çünkü gündelik hayatın derin bir krize girmesi sonucu çekilen acıya karşı bir tepkidir. Taleptir, çünkü içine girilen bu krizle yüzleşip, içine yabancılaşmanın olmadığı, anlamlı ve keyifli bir hayatı yaşamak istemektir (Harvey, 2015: 30).

Harvey açısından kent hakkı ise "şehri gönlümüze göre değiştirme ve yeniden icat etme hakkıdır". Bu hak Harvey'e göre insan hakları içinde oldukça önemli olmasına rağmen, bir o kadar da ihmal edilmiş bir haktır (Harvey, 2015: 46). Her iki düşünürün de görüşleri kent hakkını elde edebilmek için ekonomik, politik ve toplumsal anlamda kökten ve radikal bir değişimişart koşmaktadır. Kent hakkına eklemlenen katılım hakkı, gündelik yaşamda en basit bir etkinlikten politik karar alma süreçlerine kadar, sakinlerin kent üzerinde aktif bir rolünün olduğunu savunur. Purcell'e (2003: 577-578) göre bu durum mekânın üretimi noktasında aktif bir rolü beraberinde getirir. Bugün katılım hakkında karar alma süreçlerinde sermayenin ve iktidarın ön planda olduğu açıktır.

Demokratik süreçlerde sözde var olan eşitliğe rağmen, karar verici mekanizmalarda yer alan kişi ve kurumların bu kararlar sonucunda 
elde edeceği eşitsiz faydalar politik ayrımcılık olarak da değerlendirilmektedir. Yaşlıların ise kentle ilgili konularda karar alma mekanizmalarına ne kadar katılım sağlayabildiği çok az çalışılan ve genellikle görmezden gelinen bir konudur (Vanmechelen, 2012'den akt. Buffel ve Phillipson, 2018: 178; Woolrych ve Sixsmith, 2020: 19). Günümüzde, kentlerdeki hızlı ve niteliksel değişmeler yaşılıar için sürekli yenilenen bir stratejik alan haline gelmekte ve yaşııların bu stratejik alanlarda ne türden beceriler geliştirerek kentte var olabildikleri önem arz etmektedir (Şentürk ve Kurtkapan: 2017: 5).

Neoliberal kentleşme pratikleri mekânsal, ekonomik ve toplumsal ayrışmalara ve dışlanmalara sebep olurken, bu dışlanmaya dâhil olan gruplar arasında bazı yaşlılar da vardır. Kent yapılanmalarının çoğu belli bir kesime hitap ederken, toplumda oldukça önemli bir yeri olan ve gelecekte de nüfus bakımından ciddi bir artış sağlayacak olan yaşlıları dışarıda bırakmaya yönelik olarak tasarlanma tehlikesini içermektedir. Finlay ve Finn (2020) de bu konuya dikkat çekerek, yaşlı nüfus oranının kentlerde artarken, yaşlı ve mekân arasındaki ilişkinin genellikle ihmal edildiğini söylemektedirler. Onlar bu inmali "mekânın kör noktası" olarak isimlendirmişlerdir. Phillipson (2004: 969; 2010: 598) kentlerde yaşayan yaşlıların diğer bireylere nazaran daha az avantajlı olduğunu belirtmektedir. Bu nedenle Woolrych ve Sixsmith (2020) kentleşmenin hızla arttığı bir dünyada yaşlıları destekleyici mekanizmaların sağlanması gerektiğini, aksi takdirde, bu durumun onların kendilerini daha yalnız, izole olmuş ve sosyal olarak dışlanmış hissetmelerine sebep olabileceğini belirtmektedirler. Çünkü küresel piyasalarda birbirleri ile yarışan kentler tarafından üretilen toplumsal mekânlar yaşlıların da içerisinde bulunduğu pek çok toplumsal grupta dışlanmaya yönelik duyguların ortaya çıkmasına sebep olmaktadır (Buffel,
Phillipson ve Scharf, 2012: 601). Bu nedenle kent sosyolojisi ile gerontoloji arasında eleştirel kentleşme sosyolojisinden beslenen bir bağ kurulmalıdır (Finlay ve Finn, 2020; Moulaert, Wanka ve Drilling, 2018; Phillipson 2004; Wanka vd., 2018) fakat bu konunun kentleşme literatüründe eksik kaldığı (Wanka vd., 2018) vurgulanır. Öte yandan gerontoloji disiplininde de yaşamın ilerleyen yıllarında insanların neden bir dışlama ile karşılaştıkları oldukça kenarda kalmış bir alandır (Moulaert, vd. 2018; Scharf, Phillipson ve Simith, 2005; Walsh, Scharf ve Keating, 2016: 87). Bu eleştiriyi Finlay ve Finn (2020) ve Buffel ve Phillipson (2018) da dile getirmektedir. Bu sebeple kent sosyolojisinin gerontolojiden, gerontolojinin de kent sosyolojisinden öğreneceği çok şey vardır (Wanka vd., 2018: 28).

Kentlerde yaşlılara yönelik ortaya çıkabilecek bir diğer dışlama türü, yaşlılara atfedilen "pasif" veya "bağımlı" gibi sıfat belirten söylemlerden kaynaklanmaktadır. Bu süreçlerde hiçbir toplumsal grubun ihmal edilmemesi veya kenara itilmemesi insan hakları açısından da oldukça temel bir meseledir. Kapsayıcı toplum kuramı bağlamında düşünüldüğünde, aslında bu durumun bir hak ihlali olduğu söylenebilir. Tekeli'ye (2014: 203) göre insan hakları gibi kavramların soyut kavramlar olmaktan çıkıp somut bir hale bürünmesi yaşadığımız yerlerde yaşam pratiğine dökülmesiyle gerçekleşebilir. Bundan dolayı kent mekânları insan haklarının yaşama geçirildiği önemli yerlerdir.

\section{Yaş Dostu Kentler ve Topluluklar: Uygulamalar ve Eleştiriler}

Kentte yaşlanmaya ilişkin çalışmaların 1970'li yıllardan itibaren teorik ve ampirik olarak yoğunlaştığı görülür. Lui vd. (2009) son zamanlarda yürütülen yaşlılık çalışmalarında bu konunun giderek daha fazla çalışılan bir alan haline geldiğini ve gerek yaş dostu bir 
çevrenin nasıl oluşturulabileceği, gerekse oluşturulacak bu çevrenin devamlılığının ve sürdürülebilirliğinin nasıl sağlanacağının literatürde yoğunlaştığını belirtirler.

Son yıllarda "Yaş Dostu Kent", "Yaş Dostu Topluluk" veya "Yaş Dostu Toplum" isimlendirmeleri kentte yaşlanma, politikalar ve yaşlılık söylemlerine eklemlenen en son tartışmalardandır. Lui ve arkadaşları "Yaş Dostu Kent" ve "Yaş Dostu Topluluk" kavramlarının aynı anlamda kullanıldığını tespit etmişlerdir. Buna göre WHO "Yaş Dostu Kentler" kavramsallaştırmasını kullanırken, Kanada'da kavramın "Yaş Dostu Topluluk" ve ABD'de "Yaşanılabilir Topluluklar/Toplumlar" şeklinde, Ingiltere'de ise "Hayat Boyu Çevre" şeklinde kullanıldığı görülmüştür (Lui, Everingham, Warburton, Cuthill ve Bartlett, 2009). Bazı kaynaklarda ise "Yaş Dostu Kentler ve Topluluklar" tercih edilmektedir (Bkz: Finlay ve Finn, 2020; Woolrych ve Sixsmith, 2020). Farklı şekillerde kavramsallaştırılsa da, her bir kavram genel itibari ile aynı anlamı ifade etmekte ve ister genç olsun, isterse yaşlı, tüm yaş gruplarını kapsayacak şekilde bir kent yaşamının oluşturulmasına işaret etmektedir. Türkiye'de ise bu çalışmaların, daha çok, yaşlılık çalışmalarına eklemlenmesinin bir sonucu olarak "Yaş Dostu Kent" ifadesinin yanında, "Yaşlı Dostu Kent" kullanımının da yaygın olduğu görülmüştür (Bkz: Akoğlan Kozak, Acar ve Zencir, 2019; Akyıldız, 2016; Durdubaş, 2015). Bu çalışmada ise hem fiziki hem de sosyal unsurları işaret eden "Yaş Dostu Kentler ve Topluluklar" (YDKT) şeklindeki kullanım tercih edilmektedir.

Yaş dostu kentler tartışmaları WHO'nun 2005 yılında yayınladığı bildiri ile dikkat çekmiştir. WHO 2005 yılında duyurduğu ve hemen araştırmaya başladığı, aralarında İstanbul'un da bulunduğu, 33 şehirde yürüttüğü Yaş Dostu Şehirler Projesi'ni 2007 yılında yayımlamıştır. ○ günden bugüne küresel yaş dostu kentler ağı ile yerel yönetimler oluşturulan ağa katılım sağlayabilmektedir. Bu ilgi son yıllarda giderek büyümektedir.

WHO'nun YDKT yaklaşımı kentlerde yaşayanların yaşam kalitelerini artırma amacıyla sağlık, katılım ve güvenlik bakımından olanakları iyileştirerek aktif yaşlanmayı teşvik etmektedir (WHO, 2007: 1). WHO aktif yaşlanma kavramını yerel yönetimler vasıtasıyla uygulamaya geçirmeyi amaçlayan ilk girişim olma özelliği taşımaktadır (Moulaert ve Garon, 2016: 6). WHO yayınlamış olduğu bildiride yaşılırın kendi deneyimlerinden elde ettiği veriler doğrultusunda kentte yaşlanmaya dair sekiz kıstas belirlemiştir. Bunlar, dış mekânlar ve binalar; ulaşım, konut ihtiyacı; sosyal katılım, saygı ve sosyal içerme, sivil katılım ve istihdam, iletişim ve bilgi akışı, topluluk desteği ve sağlık hizmetleridir (WHO, 2007: 1).

Yaş dostu kent ve çevre tartışmaları, özellikle WHO'nun 2005'teki girişiminden sonra ilk başlarda Avusturya ve Kanada gibi yaşı ı nüfus bakımından yoğun olan ülkeler olmak üzere (Lui vd, 2009; Levasseur vd.,2017), dünya genelinde de dikkat çeken bir konu haline gelmiştir (Menec, Menas, Keating, Parkhurts ve Eales, 2011; Nieboer ve Cramm, 2018). Öte yandan gerek dünyada (bkz: Buffel, vd., 2012; Coleman, 2015) gerekse Türkiye'de yaş dostu kent çalışmaları özellikle son on yılda yoğunlaşmış ve bu alanda çalışmalar yapılmaya başlanmıştır (bkz: Öztürk ve Kızıldoğan, 2017; Tunçer, 2017; Tutal ve Üstün, 2009).

YDKT tartışmalarına daha ayrıntılı bakıldığında, ilk olarak yaşı sağlığı ve çevre arasında yapılmış çalışmalar dikkat çekmektedir. Menec vd. (2011) yaş dostu kentler bildirgesinde yer alan kriterler ile ekolojik yaklaşımı bir arada kullanarak bu alanın yaş, cinsiyet, gelir, fonksiyonellik, vb. gibi faktörlerden ayrılamayacağını belirtmektedir. Levasseur vd. (2017) ise Kanada'da yaş dostu bir kentte aktif yaşlılık 
için sağlık eşitliği, pozitif sağlık ve sosyal katılımın yaşlılar için önemli olan temel konular olduğunu belirlemişlerdir.

Ulusal literatürde ise Tutal ve Üstün'ün (2009) YDKT bağlamında Eskişehir'de yapmış olduğu araştırmada fiziki yapıların ve binaların özellikle ulaşılabilirlik açısından yetersiz olduğu ortaya çıkmıştır. Öztürk ve Turan Kızıldoğan (2017), Eskişehir'de yapmış oldukları yaşlılık ve mekân arasındaki ilişkiyi inceledikleri çalışmalarında ise yaşlıların kentsel mekânlara katılmalarının yaşlı sağlığı ve yaşam kalitesi açısından oldukça önemli olduğunu ortaya koymuşlardır.

Yaşlılık ve mekân (yer) arasındaki ilişkiye dair, ulusal literatür incelendiğinde, yaşlıların sosyal çevresinin ve kentteki fiziki mekanların yaşlının psikolojik, sosyal ve ekonomik durumlarını ve sağlığını nasıl etkilediğine dair spesifik çalışmaların yetersiz olduğu görülmüştür.

Öte yandan yaş dostu kent çalışmaları sadece sağlık alanı ile sınırlı kalmamış, bunun ötesine geçerek, çevre tasarımı ve mekân algısını da kapsayacak şekilde genişlemiştir (Lui vd. 2009: 116). Yaşlıların gereksinimlerine yönelik olarak yapılandırılmış bir dış mekân fiziksel veya psikolojik anlamda farklı ihtiyaçları olan pek çok yaşlı için çok önemlidir (Düzenli ve Alpak, 2017: 1). Bu nedenle yer (mekân) ve yaşlılık arasındaki ilişki hem fiziksel hem de psikolojik açıdan değerlendirilmelidir (Smith, 2009: 11). Yerleşim yerinden duyulan doyum, yaşam kalitesinin pek çok bileşeninden bir tanesidir. Hem kendi içerisinde hem de yaşlılıkta iyilik haline etki eden diğer etmenler arasında oldukça önemli bir konumdadır. Temel haklar bağlamında da ele alınabilecek olan konut ve yerleşim yerinin fiziksel kalitesi vazgeçilemez/devredilemez bir hak olarak değerlendirilir (Lawton, 1980: 309-310).

Görüldüğü gibi yaş dostu kentler öne sürmüş olduğu kıstaslar ile yaşlılığa yönelik ortaya çıkabilecek mücadele alanlarına dair kapsamlı bir teorik çerçeve sunarken, bunu pratik yaşamda test edecek pek çok çalışma yapılmıştır. Hatta Woolrych ve Sixsmth'in ifadesiyle, YDKT yaşlıların yerinde yaşlanmasını destekleyen kentsel ortamı oluşturabilmek adına kilit bir politika haline gelmiştir (2020). Fakat yaş dostu kentler teorik olarak son derece ideal bir yaklaşım sunarken, pratikte ise bu uygulamaların hayata geçirilmesi bir sorunsal olarak karşımızda durmaktadır. Diğer bir ifade ile YDKT programının hayata geçirilmesinde teori ve pratiği bir araya getirme noktasında birtakım zorluklar söz konusudur. Buradaki eksikliği anlayabilmek içinse, sosyal adalet mefhumuna yaslanan eleştirel kentleşme teorileri ile yaşlılık çalışmaları arasındaki bağlantıyı desteklemek gerekmektedir.

YDKT'yeyönelikeleştirilerbirkaç başlık altında toplanabilir. Bu eleştiriler; programın "ideal şehir" sunduğu (Buffel vd, 2012), toplumsal değişim süreçlerini göz ardı edip, her yerde aynı kriterleri geçerli kıldığı (Scharlach, 2016) ve yaşlıların heterojenliğini hesaba katmadığı (Woolrych ve Sixsmith, 2020) gerekçeleriyle temellendirilmektedir. Dahası YDKT'ye yönelik son yıllarda uluslararası literatürde oldukça eleştirel yaklaşımlar sunulmuştur. Bu yaklaşımların temel savı, neoliberal bir dünyada yaşamamızdan kaynaklı olarak ortaya çıkan kentleşme dinamiklerinin YDKT uygulamaları noktasında bazı kısıtılıklara sebep olması (Buffel ve Phillipson, 2018; Joy, 2017; 2021; Moualert ve Garon, 2016) ve programın kendisinin neoliberal rasyonaliteye çekici gelmesidir (Joy, 2017; 2021). Bununla birlikte YDKT aktif yaşlanma anlayışına temellendiği için yaşam seyri perspektifinden eksik kaldığı (Arun, 2021; Moulaert vd., 2016) da eleştirilen konular arasındadır.

Buffel ve arkadaşlarının (2012: 598-601) da belirtmiş olduğu gibi, YDKT her ne kadar demografik değişim karşısında kent planlaması ve yönetimine dair bir 
farkındalık oluşturma amacı gütse de hızlı küresel etkilerin ve ekonomik değişimlerin yaşandığı, farklılıkların ve zıtlıkların bir arada barındığı modern kentlerde yeterince değerlendirilmemiş bir programdır. Bu nedenle onlar programı "ideal şehir" sunduğu için eleştirirler. Bu ideal şehir ise evrensel kriterlere göre inşa edilmekte, farklılıkları göz ardı edebilmektedir. Konuya benzer bir yorum getiren Scharlach (2016) bir kenti yaş dostu yapacak unsurların toplumdan topluma değişebileceği, fakat bu noktada YDKT rehberinin yeterince açık olmadığını söyler. Yaşlılık deneyiminin heterojenliği ve bunun eşitsizliğe olan etkilerinin anlaşılması noktasında (Liira vd. 2018) YDKT'nin sınırlı bir görüşe sahip olduğunu tartışılmaktadır. Bu heterojenlik yaşlanma süreci boyunca ortaya çıkabileceği gibi, aynı zamanda bir toplulukta veya kentte sosyal, kültürel veya politik süreçler yoluyla da ortaya çıkabilir (Woolrych ve Sixsmith, 2020: 24).

Tüm bunlardan dolayı, YDKT, ekonomik tasarruf planlarından kaynaklı olarak ortaya çıkabilecek baskılar, politik engeller, tek tipleştirmeler ve yaşçı (ageist) tutumlar gibi kısıtılıkları da göz önünde bulundurmalıdır (Buffel ve Phillipson, 2018: 178). Joy (2021) ve Buffel ve Phillipson (2016) YDKT programın uygulanmasındaki problemleri daha derinlikli anlayabilmek adına eleştirel kentleşme literatürüne ihtiyaç olduğunu vurgular. Merkezi devlet rasyonalitesi ile yerel yönetimler ve kâr amacı gütmeyen yerel kuruluşlar arasındaki ilişkiler ise bu noktada oldukça önemli aktörler olarak görünmektedir.

Kentleşme sürecinde etkili olan ekonomi politiğin yaş dostu kentler oluşturabilme noktasında eleştirel bir okumasının ortaya konması son derece önemlidir. Phillipson'ın da belirttiği gibi, yeni "kent çağı"nın yaş dostu kentler inşa ederek farklı yaş ve sosyal gruplara dâhil olan bireyleri ne kadar bir araya getireceği ve ne türden fırsatlar yaratabileceği muğlâktır. Çünkü hizmet ve kaynaklara erişime olan eşitsizliklerden kaynaklanan kent mekânlarındaki çatışmalar butürden uygulamaların hayata geçirilmesinin önündeki engellerdir. Kentlerdeki yenileme çalışmaları, konut yapma tarzındaki değişme, şehir merkezlerinin dönüştürülmesi ve soylulaştırma gibi pratikler bu noktada önemli parametreler olarak karşımızda durmaktadır. Ayrıca, şehirdeki değişim ve dönüşüm noktasında yaşlıların karar alma süreçlerine katılım noktasındaki eksiklikleri onların kente yabancılaşması ve güçsüz hissetmeleri ile sonuçlanabilme tehlikesini taşımaktadır (Phillipson, 2016: viii).

Modlich (2011) ve Scharlach (2012), YDKT'deki eksikliklerin genel olarak merkezi hükümetlerin maliyet azaltma politikaları ekseninde, yerel yönetimlere sağlamakta zorlandığı kaynak ve desteklerin yetersizliğine bağlamaktadır (Akt. Joy, 2021). Bu nedenle merkezi yönetim ve yerel yönetim arasındaki güç, kaynak ve destek konularındaki çatışmalar veya anlaşmazlıklar, bu programın uygulanma noktasında zorluklara yol açabilmektedir. Joy programın yerel ölçekte uygulanmaya çalışıldığında altyapı eksiklikleri, ulaşımdaki kısıtılıklar, vb. gibi sebeplerle yaşlı nüfusun ihtiyaçlarını karşılamada yetersiz kaldığını, çünkü YDKT'nin "yaşlanma sorunu" nu yerel politika ve aktörelere devrettiğini (2021: 4-5) ifade etmektedir. Hızlı bir demografik dönüşümün yaşandığı dünyada, kent ölçeğindeki siyaset, politika ve yönetimin, gereksinim ve ihtiyaç doğrultusunda oldukça heterojen bir profil sergileyen yaşlı yetişkinlere ne kadar cevap verebileceğini anlamak önemlidir. Fakat YDKT, politik kurumlarve aktörler ile kâr amacı gütmeyen kuruluşların yaş dostu bir çevreyi inşa etmedeki rollerinin neler olabileceği noktasında yeterince açık değildir (Joy, 2017).

Bir diğer açıdan program kentlerde yaşayan bireylerin yaşam kalitelerini artırma amacıyla yola çıkmıştır. Fakat neoliberalizmin tüketime 
odaklanması ve insan hayatındaki en mikro alanları dahi ekonomik bir rasyonaliteye dönüştürmesi yaşam kalitesinin ayrıcalıklı sınıflar tarafından deneyimlenen bir durum olmasıyla sonuçlanmaktadır. Tüketimin, turizmin, kültürel ve bilgi temelli endüstrilerin kentsel ekonomi politikte temel bir yaklaşım haline gelmesi, kentsel yaşam kalitesinin kendisini de bir tüketim nesnesi haline getirmektedir (Harvey, 2008: 31).

Tüm bunlar kısaca ifade edilecek olursa, YDKT'nin uygulanmasındaki en büyük sorunun küresel çapta uygulanan yeni kentleşme politikaları olduğu söylenebilir. Bu sebeple yaş dostu kentler programını uygulamak kent yönetimi, programı ve tasarımı açısından oldukça zorlu bir mücadele alanı gibi görünmektedir (Buffel vd., 2012: 601). Özellikle de kentsel çevrelerde giderek büyüyen eşitsizliklerin toplu etkisi ve yerel yönetimlerin bütçe kısıtlama politikaları gelecekteki yaş dostu kent uygulamaları hakkında soru işaretleri uyandırmaktadır (Buffel ve Phillipson, 2018: 175).

YDKT konusunda ileri sürülen son tartışma ise aktif yaşlanmaya dair olan eleştirileri içermektedir. Yaş dostu kent uygulamalarındaki aktif yaşlılık düşüncesinin genellikle yaşlı vatandaşlara karşı neoliberal devletin yükümlülüklerini azaltarak bu sisteme fayda sağlayan aktörler yaratma potansiyeli taşıdığı (Finlay ve Finn, 2020), yaşılıarı birer neoliberal özne olarak yeniden üreten bir program olma (Joy, 2021: 5) tehlikesini taşıdığı düşünülür.

YDKT'nin aktif yaşlanma prensibinden hareket etmesi (Arun, 2021; Buffel vd., 2012; Joy, 2021; WHO, 2007) programın yaşlıları sağlık problemleri olan bireyler olarak negatif bir yaşlılık algısı çerçevesinden çıkarıp, aktif ve kendine yeten insanlar olarak pozitif bir çerçeve içerisine almaya çalışmaktadır (Joy, 2017: 43). Fakat bu kavram birkaç bakımdan tartışılmalıdır. İlki, Joy'un (2021) da belirtmiş olduğu gibi, aktif olmayan birey neoliberal rasyonaliteye fayda sağlamaz. Bu da yaşlanan bedenin sosyal sistem için bir risk olarak düşünülmesine yol açabilir.

İkincisi, yaşlıların sosyal, kültürel, ekonomik, güvenlik, sağlık ve benzeri yönlerden mümkün olduğu kadar aktif olmasını ifade eden bu kavram, bireyin sorumluluğunu yapısal faktörlerin dışına; doğrudan kendisine atfetmektedir. Her ne kadar pozitif bir anlamı ihtiva ediyormuş gibi görünse de politik bir duruşu da sergilediğini belirtmek gerekmektedir. Diğer bir deyişle, aktif yaşlılık kavramı ekonomik sorumluluğu devletten alır ve bireyin kendisine yükler. Aktif birey sağlıklı, ekonomik katkı sağlayabilen ve kendi ihtiyaçlarını kendisi rahatlıkla görebilen, böylece sağlık ve hizmet giderlerini de kendisi karşılayabilen bir bireydir. Bu nedenle sağlıklı yaşlanma, üretici yaşlılık ve başarılı yaşlanma gibi medikal söylemlerle ilişkilidir ve genellikle bir arada ele alınır. Arun'un belirtmiş olduğu gibi, aktif ve başarılı yaşlanmanın bir arada ele alınması, sınıf ve toplumsal cinsiyet olgularını görmezden gelmektedir. Çünkü kente aktif katılım fiziksel, ekonomik veya toplumsal cinsiyetten kaynaklı olarak sağlanamadığında, aktif katılımı sağlayamayan kısım başarısız olarak nitelendirilebilmektedir (Arun, 2021: 74-75). Dolayısıyla kente katılım sağlamada yaşlı bireyin zorluk çekmesi, yapısal faktörlerin dışına, kendisine atfedilmekte, bu da özneleri kurbanlaştırmak anlamına gelmektedir (Arun, 2021: 74-75; Moulaert vd., 2016: 289).

Üçüncü olarak ise, bu çerçeve beraberinde "kazanan" ve "kaybedenleri" getirir ve dışlayıcı ve ayrımcı tutum oluşturma eğilimini besler (Walker, 2016). Bu açıdan bakıldığında yaşlılığın kendisinin neoliberal dönemde aktiflik üzerinden inşa edildiği ve bu nedenle aktif yaşlanma söylemlerinin politik olduğu söylenebilir. Buna ek olarak, Finlay ve Finn'in (2020: 2) de belirtmiş olduğu gibi, yerinde yaşlanma prensibinin daha kapsamlı bir 
uygulaması olan YDKT gibi uygulamalara yeni sermaye yatırımları ve büyüme biçimleri bir çözüm gibi sunularak, sağlık harcamaları ve sosyal altyapı harcamalarındaki giderler ve devletin sorumluluğu minimize edilir.

\section{Kesişimsellik ve Hak Temelli Bakış Açısı}

Kentlerde yaşayan yaşlıların deneyimlerini; karşılaştıkları fırsat ve avantajları yahut dışlanma, ayrımcılık veya eşitsizlikleri daha iyi anlayabilmek adına, bireysel ve yapısal faktörlerin kümülatif bir şekilde yaşlılık döneminde nasıl bir rol oynadığı çok önemlidir. Bu noktada genel anlamda gerek sosyal bilimlerde gerekse daha özel olarak yaşlılık çalışmalarındaki kesişimsellik (intersectionality) kavramının bu eşitsizlikleri anlamadaki rolü büyüktür. Kesişimsellik; yaş, cinsiyet, sınıf, ırk, gibi sosyal kimliklene dayalı (Hankivsky ve Cormier, 2011: 217), yaşam deneyimlerini ve fırsatlarını, kümülatif bir biçimde şekillendiren yapısal engellerle kesişen ve farklı sosyal kategorilerde yer alan bireyleri anlamayı sağlar (Woolrych ve Sixsmith, 2020: 24). Yaş dostu kent oluşturma amacında bulunan çoğu girişim ise farklı etnik veya düşük gelirli yetişkinlerin ihtiyaçlarını karşılama noktasında başarı sağlamakta zorlanmaktadır (Lehning, Simith ve Kim, 2016: 9). Hatta özellikle göçmeler, mülteciler veya yoksul bölgelerde yaşayan insanların yaşamış olduğu sosyal ve mekânsal dışlanma, yaş dostu politikaların geliştirilmesi konusundaki tartışmalarda eksik kalmıştır (Buffel ve Phillipson, 2018: 182). Çünkü programın aktif yaşlanma prensibi mülteciler, dul yaşlı kadınlar, işsizler, yoksullar gibi, yapısal sebeplerde aktif olamayan toplumsal kesimleri başarısız sayma riskini taşır (Arun, 2021: 74). Bu nedenle kesişimsellik kavramı sosyo-kültürel açıdan ortaya çıkan yaş, toplumsal cinsiyet, sosyo-ekonomik statü, etnisite, vb. gibi farklılıkları analiz etmede kavramsal bir bakış açısı sunar (Woolrych ve Sixsmith, 2020: 24).
YDKT programının aktif yaşlanma prensibine dayanması ile eleştiren Arun (2021: 75), yaşlanmanınyaşamboyu devameden birsüreç olduğunu ve yaşamın ilk yıllarındaki kazanım ve zorlukların yaşamın ilerleyen dönemlerine sirayet edeceğine vurgu yapar. Bu açıdan o, yapısal eksiklikler, sınıf ve toplumsal cinsiyetin kesişimi ile meydana gelebilecek her türlü avantaj ve dezavantajlar noktasında insan Hakları Kentleri Göstergeleri'nin yol gösterici olabileceğini belirtir.

Bugün modern kentler ve yaşamın ilerleyen yıllarındaki mücadele alanlarına dair kapsamlı çalışmalara ihtiyaç vardır (Phillipson, 2010), fakat hala kent sosyolojisi ve gerontoloji arasında sistemli bir ilişki nadiren oluşturulabilmektedir (Phillipson, 2004).

YDKT rehberindeki sekiz kriterden bir tanesi yaşılıar da dâhil olmak üzere, tüm sosyal grupların kentsel konularda söz sahibi olmasını ifade eden katılım hakkıdır. Yaşlı vatandaşlar ve devlet arasındaki toplum sözleşmesi (social contract) yaş dostu uygulamaların konusu olmalıdır (Joy, 2021: 6). Buffel ve arkadaşlarının (2012: 607) da belirttiği gibi, YDKT yaklaşımının mevcut potansiyellerini yerine getirebilmesi ve kentlerde yaşayan yaşlıların da dâhil olduğu tüm toplumsal grupların yaşam kalitelerinin artırılması için yeni bir kentsel vatandaşlık anlayışının geliştirilmesi gerektiği tartışılmaktadır. Burada ise Lefebvre'in kent hakkı düşüncesinden ileri gelen bir yön yol gösterici olabilmektedir. Çünkü YDKT'deki katılım hakkı ile kent hakkı yaklaşımındaki sahiplenme ve katılım hakkı gibi kavramlar birbirleri ile yakından ilgilidir. Kent hakkı, temel bir hak olarak yurttaşlık, hemşerilik, vatandaşlık haklarına dâhildir. Joy'un da belirtmiş olduğu gibi, kent hakkı, hizmetlerin ve olanakların yeniden dağıtımındaki karar alma süreçlerine vatandaşların demokratik katılımını mümkün kılan geniş anlamdaki bir vatandaşlık yaklaşımını ihtiva eder (Işın, 2008'den akt. Joy, 2017: 46). Yaş dostu kentler 
programının daha etkili olabilmesi, kent vatandaşlığı ve hakları ile kentte yaşamanın getireceği faydaları ele alarak mümkün olabilir (Phillipson, 2010). Yaş dostu kentler, kent planlamasında ve politikalarında yaşılıarı karar alma süreçlerine dâhil etmeye olanak vererek, onların güçlenmelerini sağlamalıdır (Pillipson, 2016).

Bugün ortaya çıkan kentsel pratiklerde yaşlı bireyin ihtiyaç ve isteklerini dikkate alan pek az yönetim politikası bulunmaktadır. Buffel ve arkadaşları (2012) kentleri daha "yaş dostu" yapabilmek için radikal girişimlere ihtiyaç olduğunu belirtmektedir. Kentsel yeniden üretim politikaları yaşlıları, içerisinde yaşadıkları kent ile bütünleştirerek, onların deneyim ve tecrübelerinden faydalanılarak geliştirilmelidir. Buffel ve Phillipson (2018: 180) bu noktada yerel, bölgesel ve ulusal düzeylerde önemli paydaşlarla (stakeholders) yapılacak iş birliğinin sağlanması gerektiğini savunurlar. Dahası, Fudge vd, (2007) yaşlılar için ve yaşlılar hakkında bir çalışma yapılmasını değil, yaşılıarı merkeze alarak, onlarla birlikte veya onlar tarafından yapılacak çalışmalara ihtiyaç olduğunu belirtmişlerdir (akt. Buffel ve Phillipson, 2018: 183; Buffel vd., 2012).

Modern kapitalist kentlerde yaş।ı ve yaşanılan mekâna ilişkin yaşam seyri perspektifi ile (Arun, 2021), bölgesel farklılıkları ve yapısal faktörleri de göz önünde bulundurarak yaş dostu politikalar geliştirilmelidir. Bu sebeple modern kapitalist toplumlarda yaşlı ve mekân arasındaki ilişkiyi ele alacak daha geniş bir perspektife ihtiyaç vardır. Hak temelli yaklaşımlar bunlardan bir tanesidir. Dahası toplumu daha yaşanılabilir ve elverişli hale getirmek üzere uygulanan dönüştürücü (transformative) paradigmadan hareket edecek çalışmalara da ihtiyaç vardır. Çünkü dönüştürücü paradigma, özneleri çalışmanın içerisine dahil ederek, onlarla birlikte hareket eder. Kent hakkını tam anlamıla pratik etmede ve toplumsal mekânlara katılım, erişim ve ulaşım hakkını elde etmede bugün dönüştürücü paradigmalara ihtiyaç vardır.

\section{Sonuç ve Tartışma}

Nüfus yaşlanması ve kentlerdeki hızlı nüfus artışı ile meydana gelen küresel değişmeler, kentte yaşlanma konusunu giderek daha fazla çalışılması gereken bir alan haline getirmiştir. Yaşlıvemekânarasındakietkileşimeodaklanan çalışmalar gerek fiziksel gerekse sosyal anlamda alt yapı eksikliklerinin giderilerek, yaşlıların da dâhil olduğu tüm yaş grupları için uygun bir kent yaşamının nasıl olması gerektiğine dair bir tartışma alanı yaratmıştır. Bunlardan bir tanesi de giderek daha fazla büyüyen bir ağa sahip olan WHO'nun geliştirdiği YDKT yaklaşımıdır. Kent yaşamına dair toplumsal bir program olma özelliği taşıyan WHO'nun YDKT yaklaşımının, aktif ve başarılı yaşlanma kavramlarına temellenerek, yaşlılığı negatif bir algıdan pozitif bir algıya taşımak istediği söylenebilir. Bununla beraber, yerinde yaşlanma düşüncesini de içerisinde barındırması ve bunu uygulamaya taşıma hedefi programın birçok çalışmanın ana teması haline gelmesinde etkili olmuştur. Fakat WHO'nun YDKT programının hem aktif yaşlanmaya temellenmesi hem de teoride hedeflediği amaçları uygulamaya taşıma noktasındaki zorluklar tartışmalara sebep olmuştur. Çünkü aktif yaşlanma düşüncesi beraberinde sağlıklı, üretici ve başarılı yaşlanma tartışmalarını doğurur. Başarılı yaşlanma veya sağlıklı yaşlanma söz konusu olduğunda, bu sözcüklerin diğer taraftan bir "başarısız", bir "sağlıksız" olanı da hatırlattığını unutmamak gerekir. Yaşlılıkta yaş ilerledikçe kayıplar daha fazla olabilmekte ve bu nedenleyaşlının yaşamında fiziksel, bilişsel, sosyal, ekonomik anlamda değişiklikler meydana gelebilmektedir. Bunlardan kaynaklanan sebepleri minimize edebilen yaşlının "başarılı"/"sağlıklı", diğerlerinin "başarısız"/"sağlıksız" olarak nitelendirilmesi ayrımcı ve dışlayıcı bir bakış açısını doğurma riskini taşır. Ekonomik anlamdaki kayıplar ve kadınların erkeklerden daha fazla yaşaması 
(bkz: yaşlııı̆ın kadınsallaşması) gibi faktörlerle beraber düşünüldüğünde, başarılı ve aktif yaşlanma kavramları, hatta üretici yaşlılık kavramı, yaşamın ilerleyen dönemlerinde belli bir kesime karşı olan ayrımcılığı körükleme tehlikesini doğurabilir. Bu nedenle başarılı yaşlanma gibi kavramsallaştırmalar, üretme ve aktivite yeteneğini kaybetmiş, fiziksel engelleri olan veya kısaca aktif olamayan diğer tüm toplumsal grupları da kapsayacak bir anlam çerçevesine taşınmalıdır. Bunu yapabilmek için bireysel faktörleri değil, en temelde, yapısal ve yaşam boyunca kümülatif olarak biriken dezavantajları değerlendirmek gerekmektedir.

Benzer bir tartışmayı Arun (2021) ve Moulaert ve arkadaşları (2016) da yürütmektedir. Arun'un (2021) belirttiği gibi toplumsal yapıda görülen eşitsizlikve dengesizliğinyaşamıntüm evrelerine yansıması yaşam seyri perspektifi ile ele alınması gereken bir konudur. Çünkü kişinin yaşamında mevcut olan eşitsizlikler yaşlılık dönemine de taşınmaktadır. Moulaert vd. (2016) ise güçlendirme (empowerment) yaklaşımından hareketle hem aktif hem de sağlıklı yaşlanmanın güçlü yanlarına dayanarak yaşam seyri perspektifi ile bütünleşmiş bir bakış açısını önerirler. Onlar bu yaklaşımın yaşlılık profillerindeki farklılığı ön plana çıkaracağını ve böylece aktif ve sağlıklı yaşlılık anlayışındaki sınırlılığın ötesine geçebileceğini vurgularlar.

Son yıllarda kentlerde yaşanan değişmeler ve neoliberal rasyonalite ise yaşlılık dönemine sirayet eden eşitsizlikleri daha da derinleştirmektedir. Harvey'in dile getirdiği gibi, yaşam kalitesinin kendisinin dahi bir tüketim ürünü haline gelmesi (2008), kentlerdeki tüketim kültürünün, akışkanlık ve hızlı akan şehir yaşamının tüm topluma nüfuz etmesiyle kendisini belli etmektedir. Kentlerin giderek özelleşmiş kamusal mekânlar halini alması (Harvey, 2015), kent mekânlarına ve imkânlarına erişmede sınıfsal ve toplumsal eşitsizliğe neden olmaktadır.
Tüm bunlar kent sosyolojisinde geniş çaplı tartışılan meseleler iken, yaşlılar birer özne olarak çoğu zaman bu konunun dişında kalmaktadır. Meselenin yaş dostu kentler tartışmalarına uzanması ise tam da burada karşımıza çıkmaktadır. Sermaye birikim süreçleri, soylulaştırma, kentsel dönüşüm ile birlikte pek çok toplumsal grup yerinden edilmektedir. Yaşlanma çalışmalarındaki "yerinde yaşlanma" kavramsallaştırmasının, güncel uygulamalarından bir tanesi haline gelen YDKT programının (Moulaert vd, 2018) potansiyellerini yerine getirebilmesi için günümüz şehircilik anlayışında da radikal değişikliklere ihtiyacın olduğu aşikârdır. Dolayısıyla bu programın mevcut hedeflerini yerine getirebilmesi için kentsel değişimde özne olarak, yaşlıların, hatta tüm toplumsal grupların fikirlerinin alınacağı bir vatandaşlık katıımını sağlayabilmesi, bunun için imkânlar yaratabilmesi gerekmektedir. Bu yolda atılacak önemli adımlardan bir tanesi ise, özellikle yaşlılık başlığı altındaki dernek ve sivil toplum kuruluşları ile iş birliği yapılması olabilir. Fakat Türkiye gibi, sivil toplumun öneminin henüz tam olarak kavranamadığı ülkelerde, bunun da öncesinde atılması gereken adımın, yaşlılık başlığı altındaki kar amacı gütmeyen kuruluşların yaygınlaşmasını sağlamak olabilir. Hatta bunun da ötesine gidilerek, Lui ve arkadaşlarının (2009) ve Buffel ve Phillipson'ın (2016) önerdiği gibi, yönetimdeki yerel paydaşlar ve özel sektörün dahi senkronize iş biriliği oldukça önemli olacaktır. Böyle bir model ekonomik tasarruf planlarından kaynaklı olarak ortaya çıkabilecek baskı ve politik engelleri (Buffel ve Phillipson, 2018; Woolricyh ve Sixsmith, 2020) aşabilmede etkili olabilir. Tüm bunlar aslında bir taraftan yaş dostu kentler oluşturma önündeki zorlukları ortaya koyarken ve bu konuda bir farkındalık ortaya koymaya çalışırken, diğer yandan bu yazının en başında belirttiği gibi, yeni kentleşme sosyolojisi ile gerontoloji çalışmaları arasındaki bağın güçlendirilmesini, teori ve pratikte birbirini tamamlayan çalışmaların 
yapılması gerektiğini göstermektedir.

Şimdiye kadar yapılan tartışmalardan hareketle, bu çalışmanın önerisi ilk olarak, yukarıda bahsedilen iki disiplin arasında sahaya dayalı çalışmalara ağılık verilmesi gerektiğidir. Kentte yaşlanmaya eleştirel yaklaşımlar her iki disiplin içerisinde görece eksik kalmış bir alandır. Oysaki bu iki disiplinin kesişiminden doğacak bakış açısı, gittikçe yaşlanan dünyada eşit yaşam koşullarını oluşturabilmek adına iyi bir başlangıç olacaktır. İkinci olarak ise kent hakkı perspektifindeki, bireyleri karar alma süreçlerine dâhil etme anlamını ifade eden katılım hakkının yukarıda ayrıntılı olarak bahsedilen grupları da kapsayacak şekilde genişletilmesidir. Dahası, bu çalışma, dönüştürücü (transformative) paradigmadan hareketle ulusal, yerel, bölgesel ve akademik çalışmalara yaşlıların kendilerinin dâhil edilerek çalışmalarının gerçekleştirilmesini savunmaktadır. Arun'un belirtmiş olduğu gibi, kentte yaşayan ana aktörlerden bir tanesi olan yaşlılar, yönetimlerin değerlendirme, izleme ve geliştirme çalışmalarında rol almalıdır (2021: 76). Böylece kentsel hakları deneyimlemede gerçek yaşam eyleyenleri olarak yaşılıar daha fazla söz sahibi olabilecek ve kendilerini ifade edebileceklerdir. 


\section{Kaynakça}

Akoğlan Kozak, M , Acar, D , Zencir, E . (2019). Üçüncü Yaş Turizminin Geliştirilmesinde Yaşlı Dostu Şehir (YDŞ) Konsepti . Turizm Akademik Dergisi , 6 (2) , 99-114 . Retrieved from https://dergipark.org.tr/en/pub/touraj/ issue/50389/577894.

Akyldız, N. A. (2015). İnsan-Mekân Ilişkisi Bağlamında 'Yaşlı Dostu Mekânlar'. Yayımlanmamış Doktora Tezi, Ankara: Yıldırım Beyazıt Üniversitesi.

Arun, Ö. (2020). Yaş Dostu Kentlere Doğru: Hızla Yaşlanan Bir Toplumda Yaş Dostu Çevreler Ve Hizmetler Yaratmak. İstanbul: Research Worldwide İstanbul.

Arun, Ö. (2021). Yaşlanma Göstergeleri. içinde Insan Hakları Kentleri Göstergeleri (Ed. Bahar Özden Coşgun Ve Gülin Özdemir Eroğlu). Ankara: Emsal Matbaa.

Buffel, T., Phillipson, And C. Scharf, T. (2012). Experiences Of Neighbourhood Exclusion And Inclusion Among Older People Living in Deprived Inner-City Areas in Belgium And England. Ageing And Society, 33: 89-109.

Buffel, T. And Phillipson, C. (2016). Can Global Cities Be 'Age-Friendly Cities'? Urban Development And Ageing Populations. Cities, 55, 94-100.

Buffel, T. And Phillipson, C. (2018). A Manifesto For The Age-Friendly Movement: Developing A New Urban Agenda. Journal Of Aging \& Social Policy, 30:2, 173-192, https://doi.org/10.1080/08959420.2018.1430 414.

Castells, M. (2014 [1978]). Kent, Sınıf, Iiktidar (Çev. Asuman Türkün). Ankara: Phoenix Yayınevi.
Coleman, v. J. (2015). The Greying of American Cities: Evaluating Built Environment Indicators for Ensuring an Age-Friendly City. A Thesis Submitted in Partial Satisfaction Of The Requirements For The Degree Master Of Urban And Regional Planning. Los Angeles Unıversıty Of Calıfornia.

Durdubaş, K. (2015). Yaşlı Dostu Kentler Için Eşitlik Illkesinin Sosyal Politikalar İçin Önemi. Yaşlı Dostu Kentler Sempozyumu Bildiri Kitabı.

Düzenli, T. Ve Alpak, E. M. (2017). Yaşlıların Kentsel Açık Mekan Kullanımlarının Incelenmesi: Trabzon Kenti Örneği. Yaşlı Sorunları Araştırma Dergisi, 10 (2), 1-8.

Filho, A.S. (2014). Neoliberalizm; Muhalif Bir Seçki. İstanbul: Yordam Kitap

Finlay, J. M. And Finn B. M. (2020). Geography's Blind Spot: The Age-Old Urban Question. Urban Geograpy, DOI: 10.1080/02723638.2020.1742468.

Hankivsky O, Cormier R. (2011). Intersectionality and Public Policy: Some Lessons from Existing Models. Political Research Quarterly. 64(1):217-229. DOI:10.1177/1065912910376385.

Harvey, D. (2008). The Right To The City. New Left Review.

Harvey, D. (2015). Asi Şehirler: Şehir Hakkından Kentsel Devrime Doğru.Ayşe Deniz Temiz, Çev.) İstanbul: Metis Yayınları.

Holton, R.J. (1999). Kentler, Kapitalizm ve Uygarlık (Çev. R. Keleş). Ankara: Imge Kitabevi. 
Joy, M. (2017). An Urban Revolution Through Age Friendly Cities: The Case Of Toronto. Dissertation Presented To Ryerson University in Partial Fulfillment Of The Requirements For The Degree Of Doctor Of Philosophy in The Program Of Policy Studies. Toronto: University Of Toronto.

Joy, M. (2021). Neoliberal Rationality And The Age Friendly Cities And Communities Program: Reflections On The Toronto Case. Cities, 108.

Kendig, H. (2003). Directions in Environmental Gerontology: A Multidisciplinary Field. The Gerontologist, 43 (5): 611-15.

Kurtuluş, h. (2019). Kentsel dönüşümün sessiz mağdurları yaşılıar. İçinde, Mekanda Adalet Ve Yaşlılık. Ed. Didem Danış ve Adnan Yaşar Adanalı. Beyond.İstanbul.

Lawton, M. P. (1980). Housing The Elderly: Residental Quality And Residental Satisfaction. Research On Aging, 2 (3), 309328.

Lefebvre, H. (1996). Writings on Cities. (Çev. ve Ed. Eleonore Kofman and Elizabeth Lebas). Oxford: Blackwell Publishers.

Lefebvre, H. (2017). Şehir Hakkı. (Çev. Işık Ergüden). İstanbul: Sel Yayınları.

Lehning, A. J., Smith, R. J. \& Kim, K. (2016): "Friendly" Initiatives: An Emerging Approach to Improve Communities for Vulnerable Populations. Journal of Policy Practice, DOI: 10.1080/15588742.2015.1125331.

Levasseur, M., Dubois, M. F., Genereux, M., Menec, V., Raina, P., Roy, M., Gabaude, C., Couturier, Y. And St-Pierre, C., (2017). Capturing How Age-Friendly Communities Foster Positive Health, Social Participation and Health Equity: A Study Protocol Of Key Components And Processes That Promote
Population Health In Aging Canadians. BMC Public Health, 17.

Liira, H., Mavaddat, N., Eineluoto, M.,

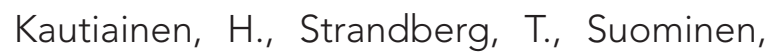
M., ... and Pitkälä, K. (2018). Health-related quality of life as a predictor of mortality in heterogeneous samples of older adults. European Geriatric Medicine, 9(2), 227-234.

Lui, C. W., Everingham, J. A., Warburton, J., Cuthill, M. And Bartlett, H. (2009). What Makes A Community Age-Friedly: A Review Of International Literature. Australasian Journal On Ageing, 28 (3), 116-121.

Marrifield, A. (2017). Yeni Kent Sorunu.(Çev. Duygu Toprak Ve Ceren Akyos). İstanbul: Tekin Yayınevi.

Menec, V., Menas, R., Keating, N., Parkhurts, G. And Eales, J. (2011). Conceptualizing AgeFriendly Communities. Canadian Journal On Aging, 30 (3), 479-493.

Mitchell, D. (2014). Kent Hakkı: Sosyal Adalet Ve Kamusal Alan Mücadelesi (Çev. Aydın Çavdar). İstanbul: Ayrıntı Yayınları.

Moore, E.G. And Pacey, M.A. (2004). Geographic Dimensions Of Ageing in Canada 1991-2001. Canadian Journal Of Ageing, 23, 5-21.

Moulaert, T., Boudiny, K. And Paris, M. (2016). Active And Healthy Ageing: Blended Models And Common Challenges in Supporting Age-Friendly Cities And Communities (in) International Comparision: Political Lessons, Scientific Avenues, And Democratic İssues (Thibauld Moulaert And Suzannegaron, Eds.). Switzerland: Springer International Publishing.

Moulaert, T. And Garon, S. (2016). AgeFriendly Cities And Communities in International Comparison Political Lessons, 
Scientific Avenues, And Democratic Issues (Eds. Thibauld Moulaert And Suzanne Garon). Switzerland: Springer International Publishing.

Moulaert, T., Wanka, A. And Drilling, M. (2018). The Social Production Of Age, Space And Exclusion: Towards A More TheoryDriven Understanding Of Spatial Exclusion Mechanisms in Later Life. Sociální Studia / Social Studies, Masaryk University, 15 (1): 9-23. Hal-01895265v2.

Nieboer, A. P. And Cramm, J. M. (2017). Age-Friendly Communities Matter For Older People's Well-Being. Journal Of Happiness Studies, 19, 2405-2420.

Öztürk, A. Ç. Ve Turan Kızıldoğan, E. (2017). Yaşlı Bireylerin Kentsel/Kamusal Mekanları Kullanım Analizi: Eskişehir Örneği. Yaşlı Sorunları Araştırma Dergisi, 10 (1), 1-13.

Phillipson, C. (2004). Urbanısatıon And Ageıng: Towards A New Environmental Gerontology. Ageing And Society, 24 (6): 963-72. Doı: 10.1017/S0144686x04002405.

Phillipson, C. (2010). Ageing And Urban Society: Growing Old in The 'Century Of The City'. In The Sage Hanbook Of Social Gerontology. (Eds. Dale Dannefer And Chris Phillipson). London: SAGE Publications Ltd.

Purcell, M. (2003). Citizenship And The Right To The Global City: Reimagining The Capitalist World Order. International Journal Of Urban And Regional Research, 27 (3), 56490.

Savage, M. And Warde, A. (1993). Urban Sociology, Capitalism and Modernity. London: The Macmillan Press Ltd.

Scharf, T., Phillipson, C. And Simith, A. E. (2005). Social Exclusion Of Older People In Deprived Urban Communities Of England.
Eur J Ageing (2005) 2: 76-87 DOI 10.1007/ S10433-005-0025-6.

Scharlach, A. E. (2016). Age-Friendly Cities: For Whom? By Whom? For What Purpose? (in) International Comparision: Political Lessons, Scientific Avenues, And Democratic İssues (Thibauld Moulaert And Suzannegaron, Eds.). Switzerland: Springer International Publishing.

Smith, A. E. (2009). Ageing In Urban Neighbourhoods. Bristol University Press.

Stavrides, S. (2016). Kentsel Heterotopya: Özgürleşme Mekanı Olarak Eşikler Kentine Doğru. (Çev. Ali Karatay). İstanbul: Sel Yayıncilık.

Şentürk, M. (2019). Yeni Kentleşme Dinamikleri Ve Kentte Yaşlılık, İçinde, Mekanda Adalet Ve Yaşlılık. Ed. Didem Danış ve Adnan Yaşar Adanalı. Beyond.İstanbul, 5, 61-69.

Şentürk, M. ve Kurtkapan, H. (2017). Yaşlılığın Mekansallaşması: Kadıköy Moda'daki Bir Apartman Üzerine Nitel Bir Çalışma. Senex Yaşlılık Çalışmaları Dergisi, 1, 4-19.

Tekeli, i. (2014). Kent, Kentli Hakları, Kentleşme Ve Kentsel Dönüşüm. IIlhan Tekeli Toplu Eserler-20. Tarih Vakfı Yayınları.

Torlak, S. (2016). Mekân Meselesine Bir Giriş. Içinde, Mekan Meselesi (Ed. Soner Torlak Ve Önder Kulak). İkinci Baskı. İstanbul: Tekin Yayınevi.

Tunçer, M. (2017). Urban Ageing and the Right to the City: Experiences of Elderly in Kadıköy. Dissertation. Sociology MA Programme. İstanbul: İstanbul Bilgi University.

Tutal, O. Ve Üstün, B. (2009). Yaşlılık Ve Yaş Dostu Kentler: Eskişehir. Yaşlı Sorunları Araştırma Dergisi, 1, 1-23. 
United Nations, Department of Economic and Social Affairs, Population Division (2017). World Population Prospects: The 2017 Revision, Key Findings and Advance Tables. Working Paper No. ESA/P/WP/248.

Walker, A. (2016). Population Ageing From A Global And Theoretical Perspective: European Lessons on Active Ageing in Age-Friendly Cities An Communities (in) International Comparision: Political Lessons, Scientific Avenues, And Democratic issues (Thibauld Moulaert And Suzannegaron, Eds.). Switzerland: Springer International Publishing.

Walsh, K., Scharf, T. And Keating, N. (2016). Social Exclusion Of Older Persons: A Scoping Review And Conceptual Framework.
European Journal Of Ageing, DOI 10.1007/ S10433-016-0398-8.

Wanka, A., Moulaert, T. And Drilling, M. (2018). From Environmental Stress To Spatial Expulsion - Rethinking Concepts Of SocioSpatial Exclusion in Later Life. International Journal Of Ageing And Later Life, 12(2): 2551. DOI: 10.3384/ijal.1652-8670.18-402.

Woolrych, R. And Sixsmith, J. (2020). Ageıng in An Unequal World Implications For AgeFriendly Cities And Communities. CAPA, 4 (13). DOI: HTTPS://DOI.ORG/10.15210/ PIXO.V4I13.19383.

World Health Organisation (2007). Global Age-Friendly Cities: A Guide. 